\title{
Antibacterial Effects of Disulfiram in Helicobacter pylori
}

\author{
Tomomi Kobatake' \\ Keiki Ogino ${ }^{2}$ \\ Hiroyuki Sakae 3 \\ Kazuyoshi Gotoh ${ }^{4}$ \\ Akari Watanabe 5 \\ Osamu Matsushita ${ }^{4}$ \\ Hiroyuki Okada $\mathbb{D B}^{3}$ \\ Kenji Yokota'
}

'Graduate School of Health Science Okayama University, Okayama, 700-8558, Japan; ${ }^{2}$ Department of Environmental Medicine, Koch Medical School, Nankoku-shi, 783-8505, Japan; ${ }^{3}$ Department of Gastroenterology and Hepatology, Graduate School of Medicine Dentistry and Pharmaceutical Sciences, Okayama University, Okayama, 700-8558, Japan; ${ }^{4}$ Department of Bacteriology, Graduate School of Medicine Dentistry and Pharmaceutical Sciences, Okayama University, Okayama, 700-8558, Japan; ${ }^{5}$ Department of Oral Health Care and Rehabilitation, Institute of Biomedical Sciences, Tokushima University Graduate School, Tokushima, 770-850I, Japan
Correspondence: Kenji Yokota Graduate School of Health Science Okayama University, Okayama, 700-8558, Japan

Tel/Fax +8I-86-235-6846

Email yokochan@md.okayama-u.ac.jp
Background: Helicobacter pylori infection poses a risk of the occurrence of gastrointestinal diseases, such as gastric cancer. Its incidence rate is significantly reduced by eradication, and thereby, eradication therapy is generally performed. Disulfiram is an oral prescription drug mainly used for the treatment of alcohol dependence. In recent years, reports have been made on its anticancer and antibacterial effects, and thus, it has recently become an interesting subject. This study aimed to examine the antibacterial activity of disulfiram, investigate the presence or absence of its antibacterial activity on $H$. pylori, and determine whether it could be a new bactericidal drug against drug-resistant $H$. pylori.

Materials and Methods: Drug-sensitive strains of $H$. pylori and amoxicillin-resistant, clarithromycin-resistant, and metronidazole-resistant strains were used, and a growth inhibition test of $H$. pylori using disulfiram was performed. Furthermore, the expression of urease, vacuolating cytotoxin $\mathrm{A}$ (VacA), and CagA, the virulence proteins of H. pylori, was quantitatively analyzed using the Western blotting method. In addition, for $H$. pylori used in this study, the 16SrDNA sequence, a ribosomal gene involved in protein production, was analyzed to examine the presence or absence of gene mutation.

Results: Disulfiram suppressed the growth of 7 out of $12 \mathrm{H}$. pylori strains at $1 \mu \mathrm{g} / \mathrm{mL}$, and no correlation was observed between their susceptibility/resistance to current eradication antimicrobial drugs and disulfiram resistance. Disulfiram reduced the expression levels of urease, VacA, and CagA proteins. H. pylori, which showed resistance to disulfiram, tended to have fewer gene deletions/insertions in the 16S rDNA sequence; however, no specific mutation was detected.

Conclusion: Disulfiram has a bactericidal effect on $H$. pylori at low concentrations, suggesting that it can be used as a supplement for current $H$. pylori eradication drugs.

Keywords: disulfiram, Helicobacter pylori, urease, vacuolating toxin, CagA

\section{Introduction}

Helicobacter pylori is a Gram-negative spiral bacterium that inhabits the human gastric mucosa. H. pylori infection poses a risk of the occurrence of gastrointestinal diseases, such as peptic ulcer, gastric mucosa-associated lymphoid tissue lymphoma, and gastric cancer; ${ }^{1-4}$ however, its occurrence is significantly reduced by eradication. ${ }^{5,6}$ In Japan, eradication therapy using amoxicillin and clarithromycin is the primary treatment for $H$. pylori infection; however, in recent years, the eradication success rate is decreasing due to the increased incidence of drug-resistant H. pylori. ${ }^{7}$

Disulfiram is an oral administration drug marketed under the trade name Antabuse and used primarily indicated for the treatment of alcohol dependence. 
When disulfiram is orally ingested, one molecule of disulfiram is converted into two molecules of diethyldithiocarbamic acid in the gastrointestinal tract and blood and further metabolized into diethyldithiocarbamic acid methyl ester sulfoxide. When these metabolites react and bind to activation sites such as aldehyde dehydrogenase, alcohol metabolism is reduced, resulting in hangover symptoms, resulting in avoidance of alcohol inoculation. ${ }^{8}$ Disulfiram has been used as a therapeutic agent for alcohol dependence for many years; however, studies have re-focused on its anticancer ${ }^{9,10}$ and antibacterial activities in recent years. $^{11,12}$

Therefore, this study focused on the antibacterial activity of disulfiram, investigated the presence or absence of its antibacterial activity against $H$. pylori, and investigated whether it could be a new bactericidal drug against drugresistant $H$. pylori.

\section{Materials and Methods}

\section{Strains}

H. pylori strains were isolated from patients admitted to Okayama University Hospital with informed consent. Ethical approval to carry out the study was obtained a priori from the Okayama University Ethics Committee (Number 2034). H. pylori samples were collected in accordance with the 1964 Helsinki declaration and its later amendments. E-test was used to measure susceptibility to amoxicillin, clarithromycin, and metronidazole for antibacterial sensitivity. If the minimum inhibitory concentration (MIC) value of amoxicillin is $\geq 0.1 \mu \mathrm{g} / \mathrm{mL}$; clarithromycin, $\geq 2 \mu \mathrm{g} / \mathrm{mL}$; and metronidazole, $\geq 1 \mu \mathrm{g} / \mathrm{mL}$, the strain is identified as resistant to each antibiotic. Then, drug-sensitive, amoxicillin-resistant, clarithromycinresistant, and metronidazole-resistant strains were selected. Table 1 shows drug resistance values of the selected 12 strains.

\section{H. pylori Growth Inhibition Test with Disulfiram}

Whether disulfiram suppresses the growth of $H$. pylori was measured. About $20 \mathrm{~mL}$ of brain heart infusion (BHI) medium containing $5 \%$ horse serum was placed in a 50 $\mathrm{mL}$ liquid culture flask, and the medium was allowed to stand in a carbon dioxide $\left(\mathrm{CO}_{2}\right)$ incubator overnight to saturate the liquid medium with $\mathrm{CO}_{2}$. Disulfiram (SigmaAldrich) was added to a $\mathrm{CO}_{2}$-saturated liquid medium to prepare a chemical medium with a disulfiram
Table I MIC Values of $H$. pylori Strain Used

\begin{tabular}{|l|c|c|c|}
\hline Strains & $\begin{array}{c}\text { Amoxicillin } \\
(\mu \mathrm{g} / \mathrm{mL})\end{array}$ & $\begin{array}{c}\text { Clarithromycin } \\
(\mu \mathrm{g} / \mathrm{mL})\end{array}$ & $\begin{array}{c}\text { Metronidazole } \\
(\mu \mathrm{g} / \mathrm{mL})\end{array}$ \\
\hline $\mathrm{SI}$ & $<0.016$ & $<0.016$ & 0.047 \\
$\mathrm{~S} 2$ & $<0.016$ & $<0.016$ & $<0.016$ \\
$\mathrm{~S} 3$ & $<0.016$ & $<0.016$ & 0.016 \\
$\mathrm{ACI}$ & 6 & 16 & 0.32 \\
$\mathrm{AC2}$ & 0.75 & 1 & $256<$ \\
$\mathrm{AC3}$ & $256<$ & $256<$ & 16 \\
$\mathrm{CHI}$ & 0.032 & $256<$ & $256<$ \\
$\mathrm{CH} 2$ & 0.032 & $256<$ & $256<$ \\
$\mathrm{CH} 3$ & 0.023 & 12 & 96 \\
$\mathrm{MZI}$ & $<0.016$ & 6 & 0.96 \\
$\mathrm{MZ2}$ & 0.023 & 0.75 & 128 \\
$\mathrm{MZ3}$ & $<0.016$ & 0.25 & 48 \\
\hline
\end{tabular}

Abbreviations: MIC, minimum inhibitory concentration; AC, amoxicillin-resistant strain; $\mathrm{CH}$, clarithromycin-resistant strain; $\mathrm{MZ}$, metronidazole-resistant strain.

concentration of $10,5,1$, and $0 \mu \mathrm{g} / \mathrm{mL}$. As a pre-culture, H. pylori, which had been pure-cultured on BHI agar medium containing $7 \%$ horse defibrosis blood at $37^{\circ} \mathrm{C}$ for 4 days under microaerobic conditions, was suspended in a $\mathrm{BHI}$ solution containing $5 \%$ horse serum at $\mathrm{OD}_{600}$ $=1.0\left(10^{8} \mathrm{CFU} / \mathrm{mL}\right)$. H. pylori infused with $500 \mu \mathrm{L}$ each suspended medium was inoculated and cultured by shaking at $37^{\circ} \mathrm{C}$ under microaerobic conditions for 4 days. Absorbance was measured at $\mathrm{OD}_{600} \mathrm{~nm}$ every day, and the bacterial growth was confirmed by increased absorbance. Bacterial solution was collected after shaking the culture, and morphological changes of the bacteria were observed with Gram staining. A portion of the cultured medium was applied to the horse blood BHI agar medium and cultured at $37^{\circ} \mathrm{C}$ in microaerobic conditions for 7 days to confirm its effects on $H$. pylori developmental ability.

\section{Protein Expression Level Measurement}

The amount of $H$. pylori was estimated from strain absorbance in which the growth of $H$. pylori was confirmed in the growth inhibition test. When $\mathrm{OD}_{600}=0.5$, the amount of bacteria is approximately $10^{7} \mathrm{CFU} / \mathrm{mL}$. Bacterial solutions were collected from media with disulfiram concentrations of $0 \mu \mathrm{g} / \mathrm{mL}$ and $1 \mu \mathrm{g} / \mathrm{mL}$ by centrifugation. Bacteria were resuspended into distilled water with $1 \mathrm{mM}$ of protease inhibitor phenyl-methyl-sulfonyl fluoride and disrupted by ultrasonic waves in ice for $10 \mathrm{~min}$ using a device (Bioruptor, Cosmobio). A sample was prepared by diluting the same amount as the SDS sample buffer and heating at $100^{\circ} \mathrm{C}$ for $10 \mathrm{~min}$. About 10 of the prepared sample was added to 1 
well, electrophoresed at $90 \mathrm{~V}$ for $2 \mathrm{~h}$ using the SDS-PAGE, and then transferred to a polyvinylidene fluoride (PVDF) membrane at $100 \mathrm{~mA}$ for $4 \mathrm{~h}$. After the transfer, the PVDF membrane was blocked overnight with phosphate-buffered saline (PBS) containing 10\% skim milk. After washing with PBS for 5 min and 3 times, urease $(30 \mathrm{kDa})$ antibody (in house), CagA antibody (Funakoshi), or VacA antibody (Santa Cruz Biotechnology, Inc) diluted 1000-fold with $10 \%$ skim milk-added PBS were added as primary antibodies and shaken for $2 \mathrm{~h}$; horseradish peroxidase-labeled antibody (Dako) diluted 1000-fold with 10\% skim milk-added PBS was added as a secondary antibody and shaken for $1 \mathrm{~h}$; and the color was developed by Pierce ${ }^{\circledR}$ Western Blotting Substrate (Thermo Fisher Scientific), and the band was detected and quantified by chemiluminescence using the Amersham Imager 600 (Cytiva).

\section{Confirmation of Gene Mutation DNA Extraction from the Bacteria}

DNA was extracted from the strain according to the product protocol of QIAamp DNA Micro Kit (QIAGEN). The bacteria were suspended in a $1.5-\mathrm{mL}$ Eppen tube with $500-\mu \mathrm{L}$ of physiological saline and centrifuged at 15,000 rpm for $2 \mathrm{~min}$, and the supernatant was discarded. The remaining precipitate was pulverized by tapping or vortexing, added with $300 \mu \mathrm{L}$ of Nuclei Lysis Solution, and the mixture was suspended by pipetting, incubated at $80^{\circ} \mathrm{C}$ for $5 \mathrm{~min}$, and cooled at room temperature. After adding $1.5 \mu \mathrm{L}$ of RNase and mixing by inversion, the mixture was incubated at $37^{\circ} \mathrm{C}$ for $15 \mathrm{~min}$ and cooled at room temperature. Thereafter, $100 \mu \mathrm{L}$ of protein precipitation solution was added, vortexed, and then cooled in ice for $5 \mathrm{~min}$. Centrifugation was performed at $4^{\circ} \mathrm{C}$ and $15,000 \mathrm{rpm}$ for $3 \mathrm{~min}$, the supernatant was placed in a new Eppen tube, and $300 \mu \mathrm{L}$ of isopropanol was added. Thereafter, the mixture was centrifuge at $4^{\circ} \mathrm{C}$ and $15,000 \mathrm{rpm}$ for $2 \mathrm{~min}$, the supernatant was discarded, and $300 \mu \mathrm{L}$ of $70 \%$ ethanol was added. It was centrifuged again at $4^{\circ} \mathrm{C}$ and $15,000 \mathrm{rpm}$ for $2 \mathrm{~min}$, and the ethanol in the tube was carefully aspirated. After drying the tube at $37^{\circ} \mathrm{C}, 50 \mu \mathrm{L}$ of DNA rehydration solution was added and incubated at $65^{\circ}$ $\mathrm{C}$ for $60 \mathrm{~min}$.

\section{Polymerase Chain Reaction Detection and Sequence}

The sequence of $16 \mathrm{~S}$ rDNA, a ribosomal gene involved in protein production, was detected by polymerase chain reaction (PCR) using primers $16 \mathrm{~S}-\mathrm{F}$ and $16 \mathrm{~S}-\mathrm{R}$. The sequence of each primer is shown in Table 2.
Table 2 PCR Primers

\begin{tabular}{|l|c|c|}
\hline $\begin{array}{l}\text { Primer } \\
\text { Name }\end{array}$ & Sequence & $\begin{array}{c}\text { Product } \\
\text { (bp) }\end{array}$ \\
\hline I6S-F & 5-CTGAGACACGGTCCAGACTC-3 & 1055 \\
I6S-R & 5-CAAGACCCGGGAACGTATTC-3 & \\
\hline
\end{tabular}

Using the DNA of the extracted bacteria as a template, PCR was performed in a total amount of $50 \mu \mathrm{L}$. TaKaRa Ex Taq $(5$ units $/ \mu \mathrm{L})$ of $0.5 \mu \mathrm{L} ; 10 \times$ Ex Taq Buffer, $5.0 \mu \mathrm{L}$; dNTP mixture ( $2.5 \mathrm{mM}$ each), $4.0 \mu \mathrm{L}$; template, $1.0 \mu \mathrm{L}$; primer pair, $1.0 \mu \mathrm{L}$; sterile distilled water, $38 \mu \mathrm{L}$ were mixed. PCR conditions were $98^{\circ} \mathrm{C}$ for 1 -min denaturation, $98^{\circ} \mathrm{C}$ for $10 \mathrm{~s}, 60^{\circ} \mathrm{C}$ for $30 \mathrm{~s}$, and $72^{\circ} \mathrm{C}$ for $30 \mathrm{~s}$ for 35 cycles. A $5-\mu \mathrm{L}$ PCR product was electrophoresed on a $2 \%$ agarose gel for $30 \mathrm{~min}$. The gel after migration was stained with ethidium bromide for 20 min and observed by ultraviolet irradiation using an electrophoresis gel imaging device Dolphin-View (Dolphin-View, Kurabo, Japan). The DNA sample amplified by PCR was purified using the ethanol precipitation method. The sequence was outsourced to the Hokkaido System Science Co., Ltd. Samples were sequenced using the PRISM3130 Genetic Analyzer (Applied Biosystems), and sequence data were analyzed with GENETYX software.

\section{Statistical Analysis}

Statistical analysis of $H$. pylori protein expression level measurement was performed using $t$-test. The $P$-value of $<0.05$ was considered statistically significant.

\section{Results}

\section{H. pylori Growth Inhibition Test with Disulfiram}

Whether disulfiram inhibits the growth of $H$. pylori was examined using a total of 12 strains. All strains underwent complete growth inhibition in the media with disulfiram concentrations of $10 \mu \mathrm{g} / \mathrm{mL}$ and $5 \mu \mathrm{g} / \mathrm{mL}$. In the drug-sensitive (Figure 1A) and clarithromycin-resistant strains (Figure 1C), two strains were suppressed in growth in a medium with a disulfiram concentration of $1 \mu \mathrm{g} / \mathrm{mL}$, and one strain grew from the third day of culture. In the metronidazole-resistant strain (Figure 1D), two strains were suppressed in growth in a medium with a disulfiram concentration of $1 \mu \mathrm{g} / \mathrm{mL}$, and one strain grew from the 4th day of culture. Among the amoxicillin-resistant strains (Figure 1B), one strain underwent 

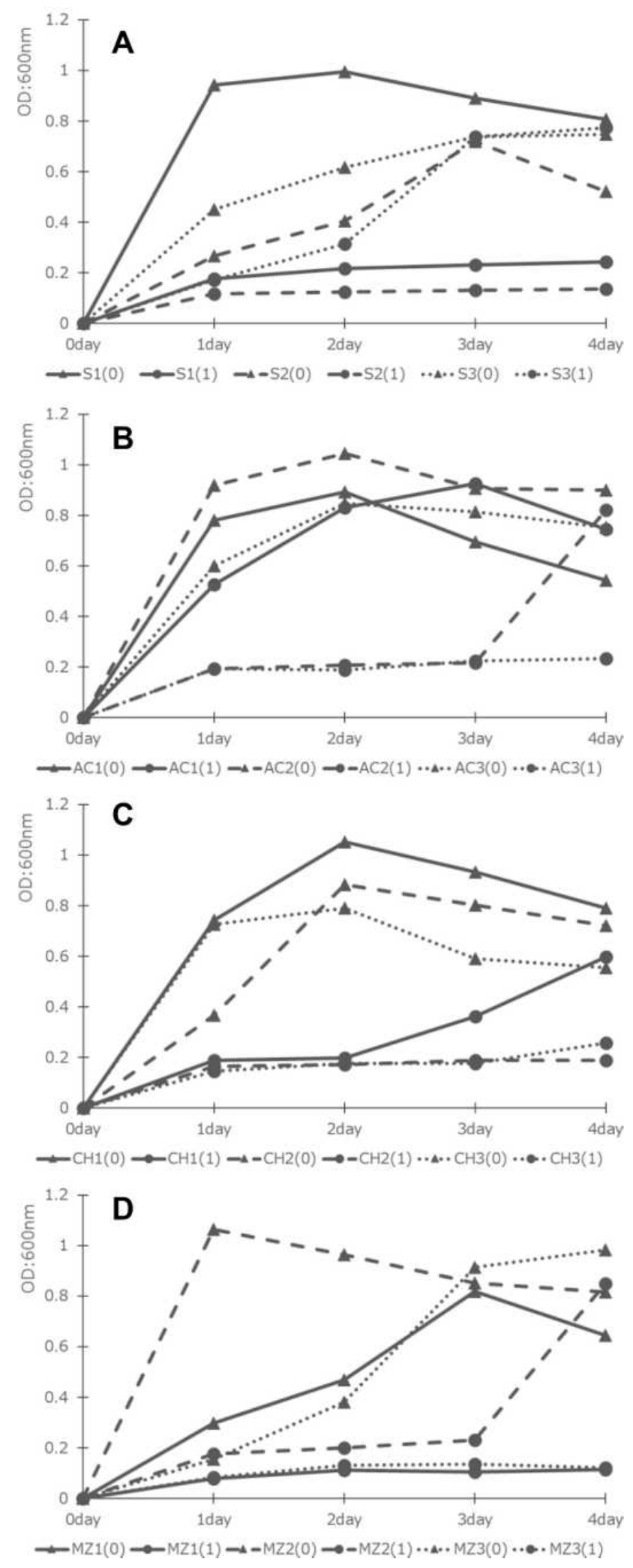

Figure I Inhibition of $\mathrm{H}$. pylori growth at a disulfiram concentration of I $\mu \mathrm{g} / \mathrm{mL}$. (A) Drug-sensitive strain, (B) amoxicillin-resistant strain, (C) clarithromycin-resistant strain, and (D) metronidazole-resistant strain. The vertical axis represents the absorbance at $\mathrm{OD}_{600} \mathrm{~nm}$, and the horizontal axis represents the number of days of the culture. Numbers in parentheses indicate the disulfiram concentration $(\mu \mathrm{g} / \mathrm{mL})$.

Abbreviations: S, drug-sensitive strain; AC, amoxicillin-resistant strain; $\mathrm{CH}$, clarithromycin-resistant strain; $\mathrm{MZ}$, metronidazole-resistant strain. 
growth inhibition in a medium with a disulfiram concentration of $1 \mu \mathrm{g} / \mathrm{mL}$, and one strain grew from the 4th day of culture, and another one strain grew from the 1st day of culture. No correlation was found between susceptibility/resistance to current disinfectants and disulfiram resistance. After collecting the bacterial solution after shaking the culture and observing the morphological changes of the bacteria using the Gram stain, the spiral shape was lost and the bacteria changed to a short rod-like (Figure 2A and B). In addition, when applied to BHI agar medium with $7 \%$ horse blood and cultured at $37^{\circ} \mathrm{C}$ for 7 days, the amount of colonies was smaller than the usual growth (Figure $2 \mathrm{C}$ and $\mathrm{D}$ ).

\section{H. pylori Pathogenic Protein Expression Level Measurement}

Bacterial proteins were compared with a disulfiram concentration of $0 \mu \mathrm{g} / \mathrm{mL}$ and $1 \mu \mathrm{g} / \mathrm{mL}$ using one from each of the drug-sensitive, amoxicillin-resistant, clarithromycinresistant, and metronidazole-resistant strain with growth confirmed in the growth inhibition test. The increase/ decrease in urease, VacA, and CagA protein expressions levels in each bacterium was measured. In the drugsensitive strain, protein expression levels of all three species decreased, and a significant difference was observed between urease and VacA (Figure 3A). Amoxicillinresistant strains had significantly reduced protein expression levels in all three species (Figure 3B). In the clarithromycinresistant strain, protein expression levels of all three species decreased, and a significant difference was observed in urease (Figure 3C). In the metronidazole-resistant strain, expression levels of urease and VacA decreased and that of CagA increased, and no significant difference was observed among the three species (Figure 3D).

\section{Confirmation of Gene Mutation}

For all $12 \mathrm{H}$. pylori strains used, the sequence of 16SrDNA, a ribosomal gene involved in protein production, was analyzed, and the presence or absence of gene mutation was examined. Table 3 shows the number of base substitutions and the number of deletions/insertions in the 16SrDNA
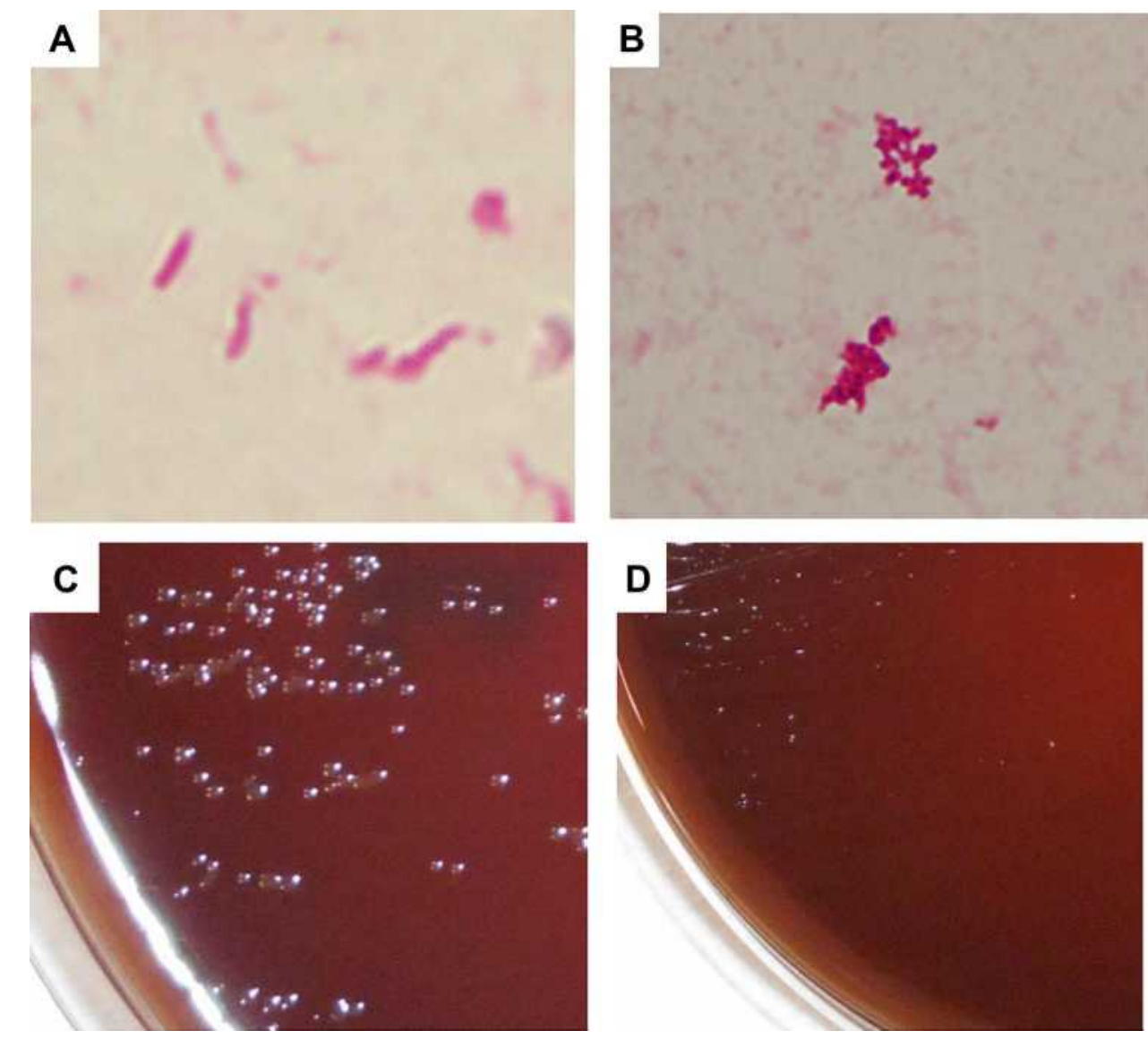

Figure 2 Bacterial morphology and colonies. (A) Morphology of $H$. pylori growth in BHI broth without disulfiram, (B) morphology of $H$. pylori with I $\mu$ g of disulfiram. After cultivation in broth, bacteria were inoculated on $\mathrm{BHI}$ agar. (C) Colony of $\mathrm{H}$. pylori transferred from $\mathrm{BHI}$ broth without disulfiram, (D) colony of $H$. pylori transferred from $\mathrm{BHI}$ broth with I $\mu$ g of disulfiram. 

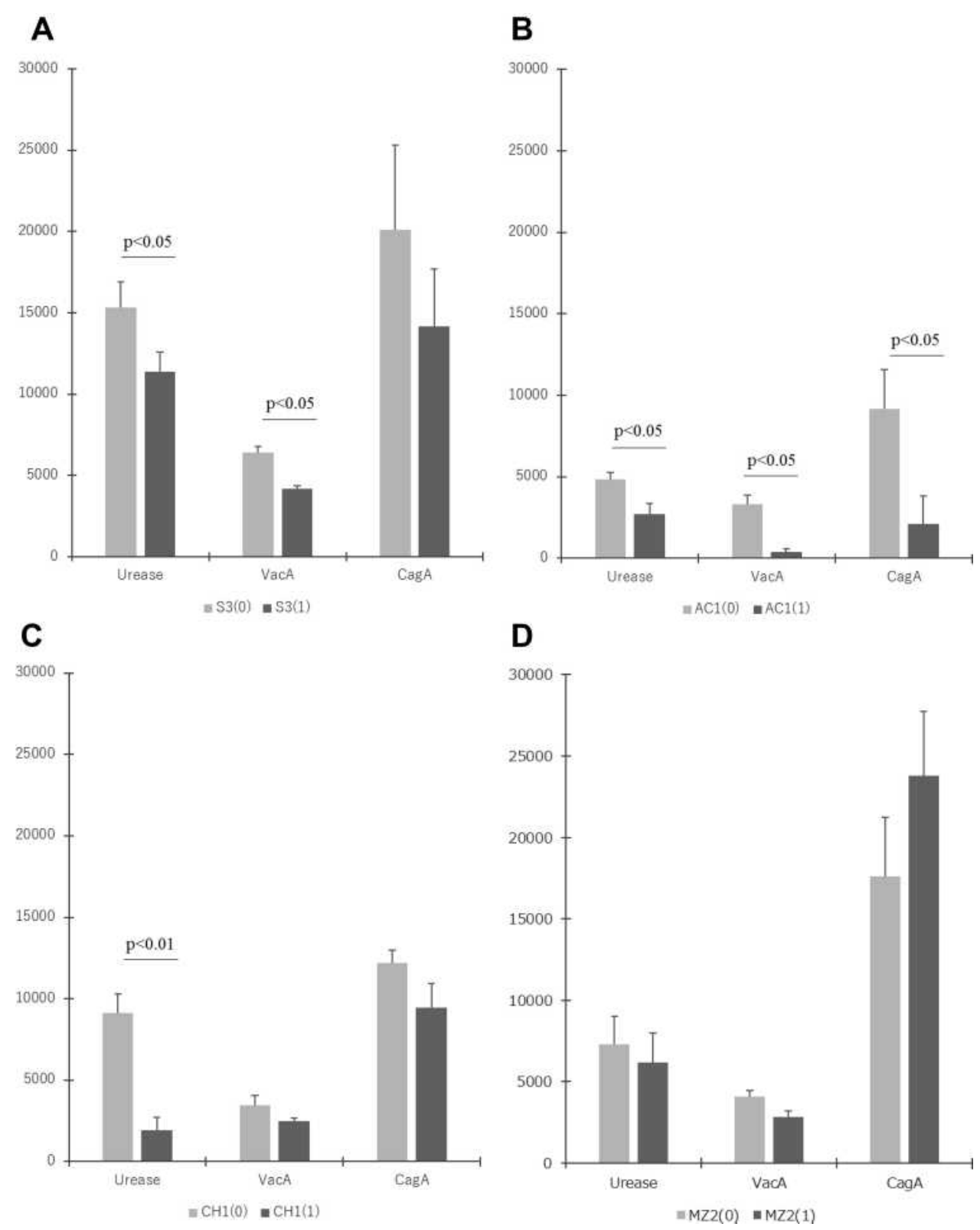

Figure $3 \mathrm{H}$. pylori pathogenic protein expression level. (A) Drug-sensitive strain, (B) amoxicillin-resistant strain, (C) clarithromycin-resistant strain, and (D) metronidazoleresistant strain. The vertical axis represents the protein expression level.

sequence. Of these, susceptible strain 3 (S3), amoxicillinresistant strain 1 (AC1), amoxicillin-resistant strain 2 (AC2), clarithromycin-resistant strain $1(\mathrm{CH} 1)$, and metronidazoleresistant strain 2 (MZ2) were resistant to disulfiram in the growth suppression test. Strains resistant to disulfiram tended to have fewer base deletions/insertions.

\section{Discussion}

Eradication therapy using amoxicillin and clarithromycin is performed for $H$. pylori infection, a risk factor for the occurrence of gastrointestinal diseases such as gastric cancer. However, in recent years, a decrease in the eradication success rate due to an increase in drug-resistant strains has become a problem, and further increase in drug-resistant strains and the emergence of resistant strains to new antibiotics should be prevented. ${ }^{13}$

Disulfiram is an oral prescription drug mainly used as a therapeutic drug for alcohol dependence and is usually taken orally in 1-3 divided doses of $100-500 \mathrm{mg}$ daily, and the maintenance dose is $100-200 \mathrm{mg}^{8}$ In this study, disulfiram suppressed the growth of 11 among 12 strains at a concentration of $1 \mu \mathrm{g} / \mathrm{mL}$ at 2 days of $H$. pylori culture 
Table 3 I6S rDNA Sequence

\begin{tabular}{|l|c|c|}
\hline $\begin{array}{c}\text { Strain } \\
\text { Name }\end{array}$ & $\begin{array}{c}\text { Number of } \\
\text { Mutation }\end{array}$ & $\begin{array}{c}\text { Number of Deletions/ } \\
\text { Insertions }\end{array}$ \\
\hline SI & 6 & 5 \\
S2 & 1 & 2 \\
S3 & 3 & 1 \\
$\mathrm{ACl}$ & 10 & 4 \\
$\mathrm{AC2}$ & $1 \mathrm{I}$ & 4 \\
$\mathrm{AC3}$ & 24 & 5 \\
$\mathrm{CHI}$ & 5 & 7 \\
$\mathrm{CH} 2$ & 3 & 0 \\
$\mathrm{CH} 3$ & 29 & 13 \\
$\mathrm{MZI}$ & 8 & 10 \\
$\mathrm{MZ2}$ & 1 & 2 \\
$\mathrm{MZ3}$ & 6 & 8 \\
\hline
\end{tabular}

and 7 at 4 days of culture. In addition, H. pylori acted on disulfiram showed poor growth of colonies in 7\% horse blood BHI agar medium, and the cells lost their spiral shape and became short rod-like. Based on these facts, disulfiram is considered to exhibit an antibacterial effect against $H$. pylori at a low concentration regardless of the sensitivity and resistance to the current $H$. pylori eradication drug.

Urease, VacA, and CagA are important proteins with pathogenic effect in the stomach. H. pylori, which neutralized gastric acid with urease, secretes VacA, a cell-vacuolating toxin, destroys host cells, and secretes CagA protein to promote carcinogenesis of host cells. ${ }^{14}$ In this study, the expression levels of urease, VacA, and CagA proteins decreased in H. pylori infection treated with disulfiram. Based on the results of the growth inhibition test, disulfiram is considered to exhibit a concentration-dependent bactericidal action by inhibiting protein synthesis of $H$. pylori.

16SrDNA is a ribosomal gene involved in protein production, and this sequence of approximately 1500 bases is used for bacterial phylogeny. The 16SrDNA sequence is abundantly registered in public databases and is considered suitable for examining sequences specific to a particular bacterial species/group. ${ }^{15,16}$ When 16SrDNA mutations were confirmed in all $12 \mathrm{H}$. pylori strains used in this study, strains showing disulfiram resistance tended to possess fewer base deletions/insertions but were susceptible/resistant to disulfiram. No specific mutations due to differences were detected. Most of these deletions/insertions were found in domain 2 (V4 region) of 16SrDNA, and we cannot find that this fact is important or associate with protein production. For clearer features, the number of samples should be increased, and further study conducted.

\section{Conclusion}

Although the genetic characteristics on the effectiveness of disulfiram against $H$. pylori can be further investigated, it exhibited a bactericidal effect on $H$. pylori at a lower concentration than when used as a supplemental drug. Therefore, disulfiram could be used as an adjunct to the current $H$. pylori eradication drug.

\section{Abbreviations}

$\mathrm{AC}$, amoxicillin; $\mathrm{CH}$, clarithromycin; $\mathrm{MZ}$, metronidazole; BHI, brain heart infusion; MIC, minimum inhibitory concentration; PCR, polymerase chain reaction.

\section{Acknowledgment}

This research was supported by Research Grant No19HA1007 of Ministry of Health, Labor and Welfare Science.

\section{Disclosure}

The authors report no conflicts of interest in this work.

\section{References}

1. IARC Working Group on the Evaluation of Carcinogenic Risks to Humans. Infection with Helicobacter pylori. IARC Monogr Eval Carcinog Risks Hum. 1994;61:177-240.

2. Blaser MJ. The bacteria behind ulcers. Sci Am. 1996;274(2):104-107. doi:10.1038/scientificamerican0296-104

3. Uemura N, Okamoto S, Yamamoto $\mathrm{S}$, et al. Helicobacter pylori infection and the development of gastric cancer. $N$ Engl $J$ Med. 2001;345(11):784-789. doi:10.1056/NEJMoa001999

4. Graham DY. Helicobacter pylori infection is the primary cause of gastric cancer. $J$ Gastroenterol. 2000;35:90-97.

5. Lee YC, Chiang TH, Chou CK, et al. Association between Helicobacter pylori eradication and gastric cancer incidence: a systematic review and meta-analysis. Gastroenterology. 2016;150 (5):1113-1124. doi:10.1053/j.gastro.2016.01.028

6. Rokkas T, Rokka A, Portincasa P. A systematic review and meta-analysis of the role of Helicobacter pylori eradication in preventing gastric cancer. Ann Gastroenterol. 2017;30(4):414-423. doi:10.20524/aog.2017.0144

7. Savoldi A, Carrara E, Graham DY, Conti M, Tacconelli E. Prevalence of antibiotic resistance in Helicobacter pylori: a systematic review and meta-analysis in World Health Organization Regions. Gastroenterology. 2018;155(5):1372-1382. doi:10.1053/j.gastro.2018.07.007

8. Franck J, Jayaram-Lindström N. Pharmacotherapy for alcohol dependence: status of current treatments. Curr Opin Neurobiol. 2013;23 (4):692-699. doi:10.1016/j.conb.2013.05.005

9. Skrott Z, Mistrik M, Andersen KK, et al. Alcohol-abuse drug disulfiram targets cancer via p97 segregase adaptor NPL4. Nature. 2017;552(7684):194-199. doi:10.1038/nature25016

10. Viola-Rhenals M, Patel KR, Jaimes-Santamaria L, Wu G, Liu J, Dou QP. Recent advances in antabuse (disulfiram): the importance of its metal-binding ability to its anticancer activity. Curr Med Chem. 2018;25(4):506-524. doi:10.2174/0929867324666171023161121 
11. Sheppard JG, Frazier KR, Saralkar P, Hossain MF, Geldenhuys WJ, Long TE. Disulfiram-based disulfides as narrow-spectrum antibacterial agents. Bioorg Med Chem Lett. 2018;28(8):1298-1302. doi:10.1016/j.bmcl.2018.03.023

12. Frazier KR, Moore JA, Long TE. Antibacterial activity of disulfiram and its metabolites. $J$ Appl Microbiol. 2019;126(1):79-86. doi:10.1111/jam.14094

13. Alba C, Blanco A, Alarcón T. Antibiotic resistance in Helicobacter pylori. Curr Opin Infect Dis. 2017;30(5):489-497. doi:10.1097/ QCO.0000000000000396

14. Yamaoka Y. Mechanisms of disease: Helicobacter pylori virulence factors. Nat Rev Gastroenterol Hepatol. 2010;7(11):629-641. doi:10.1038/nrgastro.2010.154
15. Christensen JJ, Andresen K, Justesen T, Kemp M. Ribosomal DNA sequencing: experiences from use in the Danish National Reference Laboratory for Identification of Bacteria. APMIS. 2005;113 (9):621-628. doi:10.1111/j.1600-0463.2005.apm_224.x

16. Woo PCY, Lau SKP, Teng JLL, Tse H, Yuen K-Y. Then and now: use of $16 \mathrm{~S}$ rDNA gene sequencing for bacterial identification and discovery of novel bacteria in clinical microbiology laboratories. Clin Microbiol Infect. 2008;14(10):908-934.

\section{Publish your work in this journal}

Infection and Drug Resistance is an international, peer-reviewed openaccess journal that focuses on the optimal treatment of infection (bacterial, fungal and viral) and the development and institution of preventive strategies to minimize the development and spread of resistance. The journal is specifically concerned with the epidemiology of antibiotic resistance and the mechanisms of resistance development and diffusion in both hospitals and the community. The manuscript management system is completely online and includes a very quick and fair peerreview system, which is all easy to use. Visit http://www.dovepress.com/ testimonials.php to read real quotes from published authors. 